\title{
Effect of Hydrolysis on Tannin and Carotenoid Contents, and Antioxidant Activity of Pouteria campechiana
}

\author{
Hien Xuan Tran ${ }^{a}$, Huong Lien Huynh ${ }^{b}$, Thanh Trung Nguyen \\ ${ }^{a}$ Department of Food Technology, An Giang University (VNUHCM), Long Xuyen City 880000, An Giang province, \\ Vietnam \\ ${ }^{b}$ Department of Chemical Technology, Can Tho University, Ninh Kieu District, Can Tho City 900000, Vietnam \\ ${ }^{c}$ Training Department, An Giang University (VNUHCM), Long Xuyen City 880000, An Giang province, Vietnam
}

\section{ARTICLE INFORMATION}

Article history:

Received:

Revised:

Accepted:

Keywords:

Pouteria campechiana, hydrolysis, carotenoid, tannin, phenolics, IC50

Correspondence:

Phone: +084.0918573973

E-mail: txhien@agu.edu.vn

\section{A B S T R A C T}

The medicinal properties of Pouteria campechiana fruit in Vietnam currently have not been studied much. This study was conducted to evaluate hydrolysis's effect on the carotenoid, tannin, and antioxidant activity through the correlation between IC50 and TPC values of Pouteria campechiana extract. This study examined hydrolysis conditions, such as enzyme type, enzyme concentration, temperature, and hydrolysis time. Experimental results showed that at pectinase enzyme concentration of $0.6 \mathrm{wt} \%$, cellulase enzyme concentration of 0.6 $\mathrm{wt} \%$, at hydrolysis temperature of $600^{\circ} \mathrm{C}$, and 65 minutes for hydrolysis, the study found carotenoid of $115.14 \pm 4.14(\mu \mathrm{g} / \mathrm{g})$ and tannin of $45.88 \pm 2.37(\mathrm{mgTAE} / \mathrm{g})$ in the extract. IC50 value $(7.82 \pm 0.21 \mathrm{mg} / \mathrm{mL})$ and TPC content were highly correlated $(\mathrm{R} 2=0.98)$. This study's results contributed to providing valuable scientific data on Pouteria campechiana fruit, especially for the food industry.

\section{INTRODUCTION}

Pouteria campechiana is a fruit tree widely grown in Peru, Ecuador, Chile, và Mexico and is an important part of the Spanish diet (Duarted et al., 2015); (Yahia \& Orozco, 2011). In Vietnam, the harvest season starts from July to November. Its paste is orange-yellow, typical having aroma and natural sweetness, which is a precious food that has been used as nutritious food, usually in the form of frozen powder, ice cream, candy, and Jam products (Apostolidis et al., 2009); (Yahia \& Orozco, 2011) as well as a medicine in treating a number of folk diseases for a long time. The paste contains many nutritional ingredients, such as carotenoid, tannin, especially the antioxidant components necessary for the body's activities, so Pouteria campechiana helps increase erythropoiesis in the blood, stimulating the activity of the nervous system, relieving stress, reducing cholesterol and triglyceride in the blood, preventing cardiovascular diseases and obesity, limiting myocardial infarction, and increasing the immune systems and energy efficiency (Apostolidis et al.,2009). However, the knowledge on the biological activity of Pouteria campechiana fruit has not been fully published, especially its carotenoid and tannin components and antioxidant activity. In Vietnam, the investigation of carotenoid, tannin, and antioxidant activity of 
Pouteria campechiana fruit through IC50 value has not been much researched. This study was conducted to evaluate the effect of hydrolysis on carotenoid and tannin and antioxidant activity of Pouteria campechiana extract through IC50 value. The results of the study will provide scientific data on hydrolytic conditions of Pouteria campechiana extract to obtain the highest contents of carotenoid, tannin, and effectiveness of antioxidant activity through IC50 value.

\section{MATERIALS AND METHODS}

\section{Materials and chemicals}

Pouteria campechiana fruit (200-250 g/fruit), from 120-125 days of age after fruiting, were harvested (20 fruits/tree) directly in the morning (7:00-9:00) between September and October in the garden in My Khanh, Phong Dien district, Can Tho city, Vietnam. After harvesting, they were packed in foam paper, put in a carton, transported to the laboratory during the day, and stored at room temperature $\left(30-32^{\circ} \mathrm{C}\right)$. Next, the fruits were washed in order to remove impurities and then fed into a Pulper Finisher, where the seed was separated from the paste. The paste was then stored in a freezer $\left(-18^{\circ} \mathrm{C}\right)$ for experiments.

Pectinase and Cellulase enzymes (Novoenzyme company, Denmark) and other analytical chemicals, such as tannic acid, standard gallic acid (Sigma), Acetone, Hexane, Folin-Ciocalteu reagent (Merck), 2,2-diphenyl-1-picrylhydrazyl (DPPH) (Merck), were supplied from Southern Chemical Company in Can Tho, Vietnam.

\section{Pouteria campechiana extract}

Pouteria campechiana paste after defrosting was supplemented with water in a ratio of $1: 4(\mathrm{w} / \mathrm{v})$. The mixture was pretreated with ultrasonic waves for 5 minutes and was hydrolyzed later. Factors affecting the hydrolysis, such as enzyme types (pectinase and cellulose), enzyme concentration (0$1 \mathrm{wt} \%)$, temperature $\left(40-650^{\circ} \mathrm{C}\right)$, and hydrolysis time (45-70 minutes), were examined in turn. After hydrolysis, enzymes in samples were inactivated at $85^{\circ} \mathrm{C}$ for 5 minutes, and the samples were centrifuged at $2000 \mathrm{rpm}$ for 5 minutes. The extract obtained after hydrolysis was used to determine tannin and carotenoid contents.

\section{Analytical parameters}

Tannin content was determined by the Folin-Denis method (Laitonjam et al., 2013) by establishing a calibration curve with tannic acid (TA). The tannin content is expressed in milliequivalents of tannic acid per gram of dry matter (mgTAE/g).

Carotenoid content, which is expressed in $\mu \mathrm{g}$ per gram of dry matter $(\mu \mathrm{g} / \mathrm{g})$, was determined according to AOAC 941.15.

The total phenolic content (TPC) was determined by the Folin-Ciocalteu method (Jiang, Cai, \& Xu, 2013) by establishing a calibration curve with gallic acid (GA). The TPC content is expressed in milliequivalents of gallic acid per gram of dry matter (mgGAE/g).

Antioxidant activity was assessed based on the ability to neutralize free radicals through the purple discoloration reaction of DPPH solution in methanol-based on the method of establishing a calibration curve showing the correlation between $\%$ of the free radical activity of DPPH and different sample concentrations by (Singh et al., 2011). Based on the calibration curve equation showing the correlation between the free radical scavenging percentage of DPPH and different concentrations, the IC50 value can be determined.

All experiments were repeated three times. Experimental results were analyzed by Statgraphics Centurion 15.2.11.0 software. Analysis of variance (ANOVA) with LSD test was used to determine the significant difference $(p<0.05)$ between the parameters, and the Sigma Plot 10.0.54 software was used to plot.

\section{RESULTS AND DISCUSSION}

\section{Effect of pectinase enzyme concentration}

Plant cell walls are composed primarily of cellulose, hemicellulose, pectin, protein, and phenolic compounds that bind to polysaccharides through hydrogen bonds and hydrophobic bonds. Therefore, enzymes, such as pectinase and cellulose, can be used to break down cell walls by 
hydrolysis. Effects of pectinase concentration on carotenoid, tannin, and antioxidant activity of the extract through the correlation between IC50 and TPC values were investigated with enzyme concentrations varying from 0 to $1.0 \mathrm{wt} \%$. Other parameters of the process were fixed (temperature $=40^{\circ} \mathrm{C}, \mathrm{pH}=5$, time $=45$ minutes, and cellulase enzyme concentration $=0.2 \mathrm{wt} \%$ ). The results are shown in Figures 1 and 2.
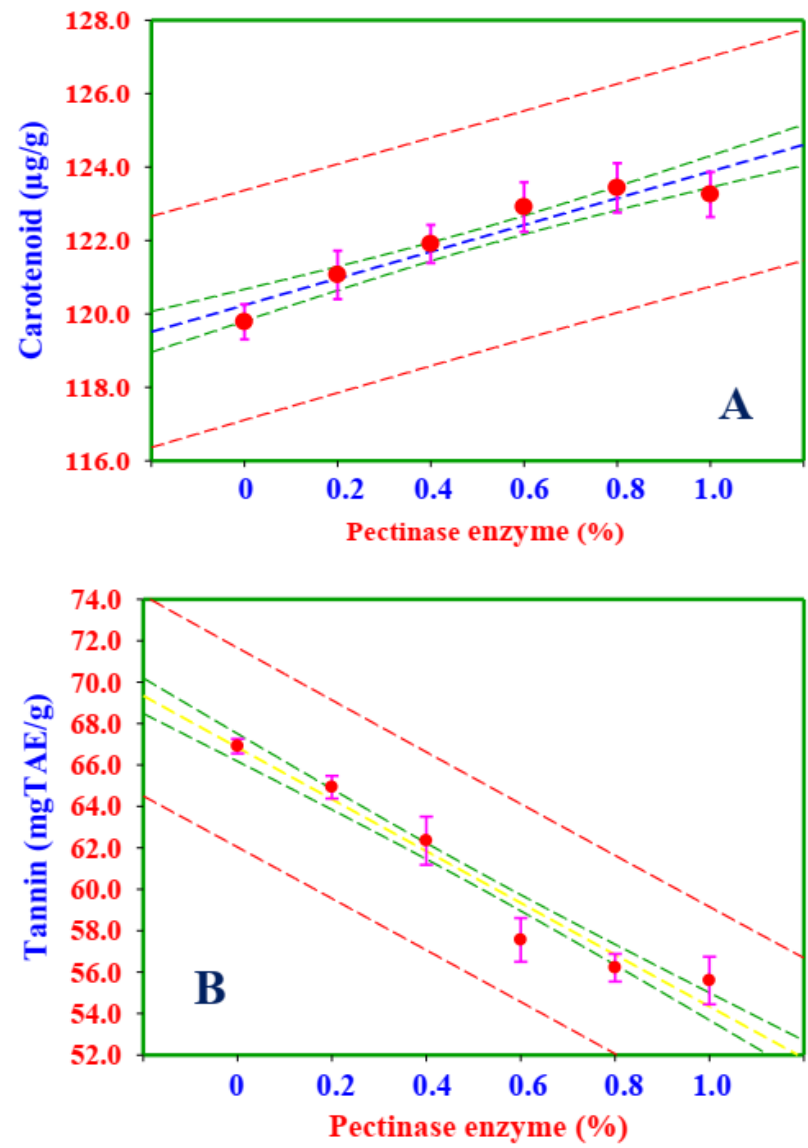

Figure 1. Effect of pectinase enzyme concentration on carotenoid (A) and (B) tannin

After being added to the extract, the Pectinase enzyme will, in turn, split constituents of the cell walls, break down the structure, and release the internal components (water and pigments), leading to a significantly increased amount and quality of the extract. Other research results also showed that supplementation with pectinase enzyme resulted in higher amounts of extract (Czukor \& Nyarady, 1999); (Demir et al., 2001); (Sreenath \& Santhanam, 1992); (Will, Bauckhage, \& Dietrich, 2000). Results in Figure $1 \mathrm{~A}$ showed that carotenoid content was directly proportional to pectinase enzyme concentration, i.e., an increase in pectinase enzyme concentration resulted in increased carotenoid content of the extract. Carotenoid reached the highest point of $123.43 \pm 1.67(\mu \mathrm{g} / \mathrm{g})$ when $0.8 \mathrm{wt} \%$ pectinases were used. Besides, ANOVA analysis showed that there was no statistically significant difference $(\mathrm{p}<0.05)$ between $0.6 \mathrm{wt} \%(122.91 \mu \mathrm{g} / \mathrm{g})$ and one wt\% $(123.25 \mu \mathrm{g} / \mathrm{g})$. The reason is that the pectinase enzyme had the ability to hydrolyze pectin molecules, enabling the compounds to escape from the paste. Previous studies revealed that pectinase would attack and broke down bonds such as ester bonds between phenol and polymer on cell walls (Manuel, 2008); pectinase enzyme supported well the carotenoid extraction process of pumpkin, leading to increased carotenoid yield (Ghosh \& Biswas, 2016). In contrast to carotenoid, when pectinase enzyme concentration increased, the tannin content of the extract tended to decrease. The lowest tannin content of $56.21 \pm 1.66 \mathrm{mgTAE} / \mathrm{g}$ was found when $0.8 \mathrm{wt} \%$ pectinases were used, and through ANOVA analysis, it can be seen that there was no statistically significant difference $(\mathrm{p}<0.05)$ between this concentration and one wt $\%$ (55.59 $\pm 2.86 \mathrm{mgTAE} / \mathrm{g})$.

In addition, because IC50 value indicates the concentration at which pectinase is able to scavenge $50 \%$ of DPPH free radicals, they are often used to compare the free radical scavenging activity of antioxidants; The smaller the IC50 value, the stronger the free radical scavenging activity of Pouteria campechiana extract. From the analytical results of TPC content in Figure 2, it is apparent that there was a negative correlation between TPC content and the free radical scavenging activity through IC50 value with $\mathrm{R} 2=0.985$. 


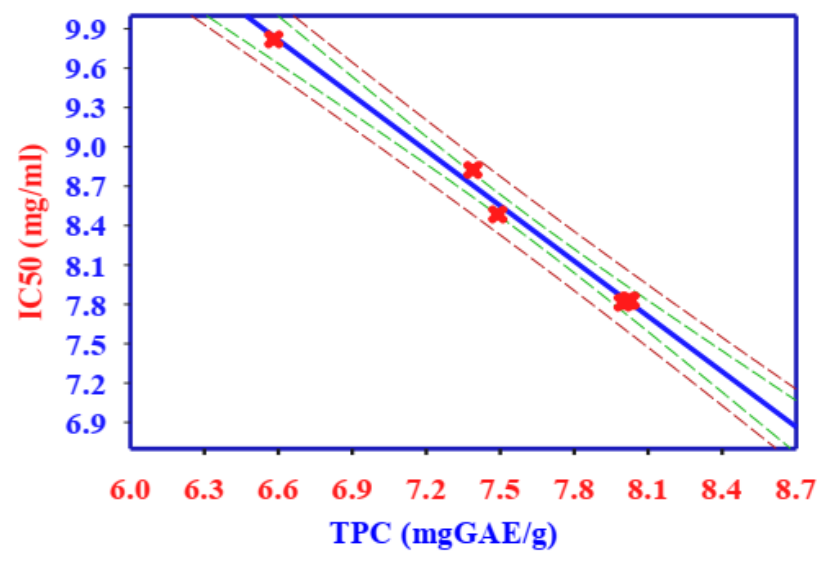

Figure 2. Correlation between IC50 and TPC by pectinase enzyme concentration

The higher the TPC content at investigated pectinase concentrations and the stronger the antioxidant activity, the lower the free radical scavenging activity through IC50 value (Miliauskas, Venskutonis, \& Beek, 2004). IC50 value decreased from $10.52 \pm 0.20(\mathrm{mg} / \mathrm{mL})$ to $8.83 \pm 0.2(\mathrm{mg} / \mathrm{mL})$ when pectinase content changed from 0 to $6 \mathrm{wt} \%$, respectively. From the above results, the optimal pectinase enzyme concentration for hydrolysis of Pouteria campechiana extract was $0.6 \mathrm{wt} \%$.

\section{Effect of cellulase enzyme concentration}

In addition, the addition of cellulase enzyme to the extract causes cellulose to split, making cell walls become loose, break down, and easily drain. Thus, internal compounds can be recovered more. Similar to pectinase, the effects of cellulase enzyme concentration on carotenoid, tannin, and antioxidant activity (correlation between IC50 and TPC) of the extract were also investigated at different concentrations ranging from 0 to $1 \mathrm{wt} \%$. Other parameters, such as $\mathrm{pH}$ (5), hydrolysis temperature $(40 \mathrm{oC})$, hydrolysis time (45 minutes), and pectinase enzyme concentration $(0.6 \mathrm{wt} \%)$, were fixed. The results are represented in Figures 3 and 4.
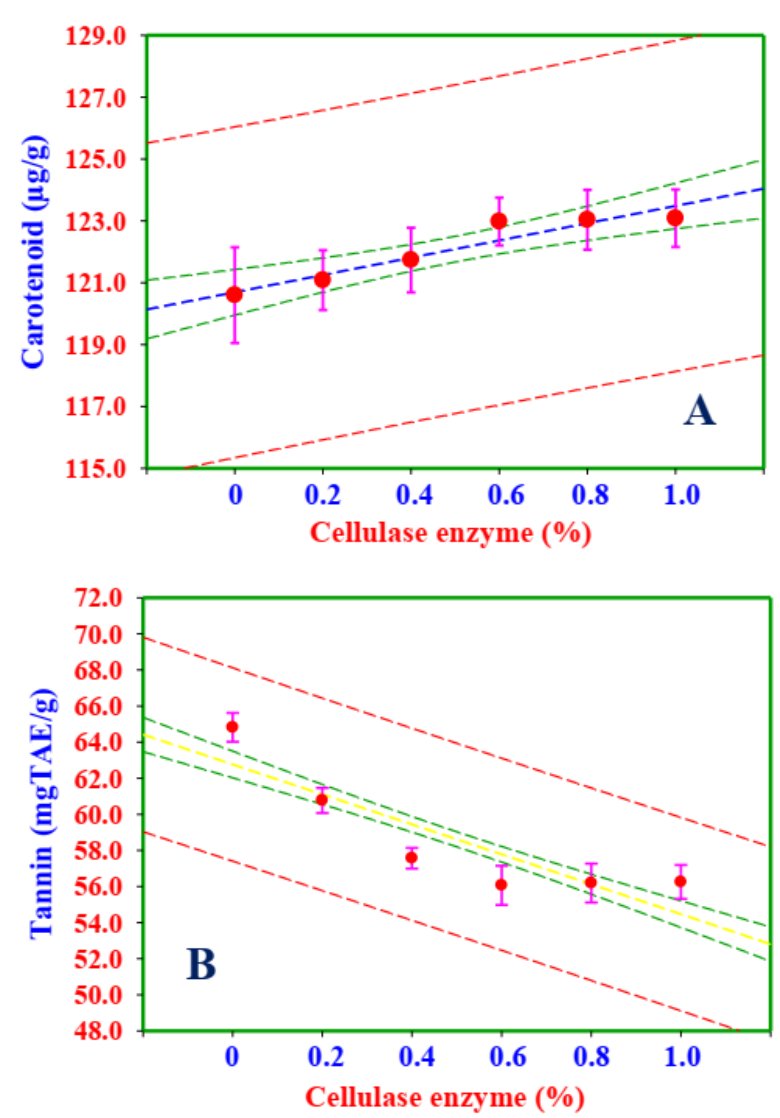

Figure 3. Effect of cellulase enzyme on (A) carotenoid and (B) tannin

According to data in Figure 3A, carotenoid content increased with increasing cellulase enzyme concentration. Cellulase concentration of $0.6 \mathrm{wt} \%$ yielded carotenoid content of $122.98 \pm 1.93(\mu \mathrm{g} / \mathrm{g})$, higher than which $0.2 \mathrm{wt} \%$ and $0.4 \mathrm{wt} \%$ yielded, and there was no statistically significant difference $(p<0.05)$ when enzyme concentration continued to increase. The higher the enzyme concentration, the more thoroughly the splitting process occurred, the more likely extract was to be released. However, to a certain extent, the number of cells was completely split, the amount of extract was released to the maximum, even if the enzyme concentration increased. On the other hand, the cellulase enzyme involved in hydrolysis helped enhance the activity of intracellular tannase, reduced tannin content in the extract, thereby decreasing of extract. Therefore, Figure 3B shows that tannin content reached the lowest value of $56.07 \pm 2.69(\mathrm{mgTAE} / \mathrm{g})$ when $0.6 \mathrm{wt} \%$ pectinases were used, and ANOVA analysis also showed no 
statistically significant difference $(\mathrm{p}<0.05)$ between this concentration and $0.8 \mathrm{wt} \%$ $(56.19 \pm 2,68 \mathrm{mgTAE} / \mathrm{g})$ and one $\mathrm{wt} \%(56.25 \pm 2.33$ $\mathrm{mgTAE} / \mathrm{g}$ ). It is discovered that these results were also similar to those of the study, which showed that tannin content in tea leaves decreased during.

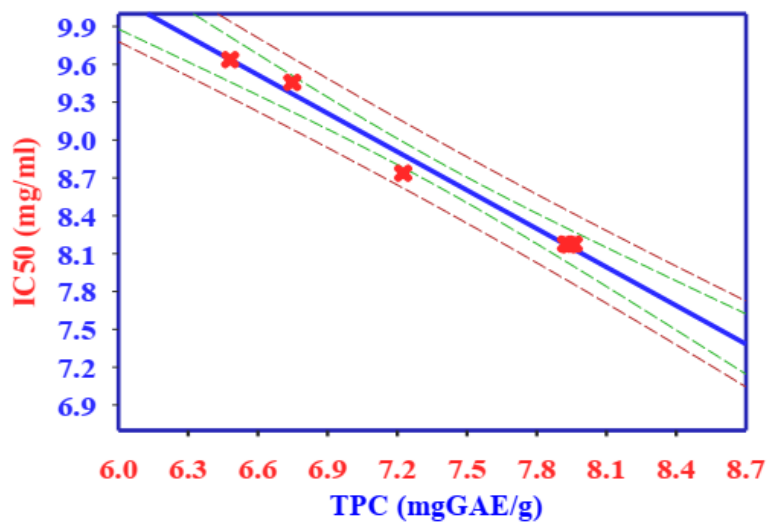

Figure 4. Correlation between IC50 and TPC by cellulase enzyme concentration

On the other hand, as can be seen from the results in Figure 4, there was also a negative correlation between TPC content and IC50 value. In other words, IC50 value dropped from 9.64 \pm 0.16 $(\mathrm{mg} / \mathrm{mL})$ to $8.48 \pm 0.10 \mathrm{mg} / \mathrm{mL}$, while TPC content rose from $7.38 \pm 0.03(\mathrm{mgGAE} / \mathrm{g})$ to $8.04 \pm 0.06$ (mgGAE/g), respectively with quite a high R2 value (0.997) of the regression equation. Based on the above analytical results, cellulase enzyme concentration of $0.6 \mathrm{wt} \%$ was selected for the next research step.

\section{Effect of hydrolysis temperature}

The use of enzymes to increase extracting efficiency has been applied in many studies to extract compounds from plants and fruits, including grapes, green tea, pomelos, tomatoes, and apples. Besides selecting the right enzyme, hydrolysis conditions are also one of the important factors affecting the release of biologically active components. Effects of hydrolysis temperature on carotenoid, tannin, and antioxidant activity (correlation between IC50 and TPC) were investigated at a temperature ranging from 40 to $650^{\circ} \mathrm{C}$ during 45 minutes, $\mathrm{pH} 5$, pectinase enzyme concentration of $0.6 \mathrm{wt} \%$, and cellulase enzyme concentration of $0.6 \mathrm{wt} \%$ (Figures 5 and 6).
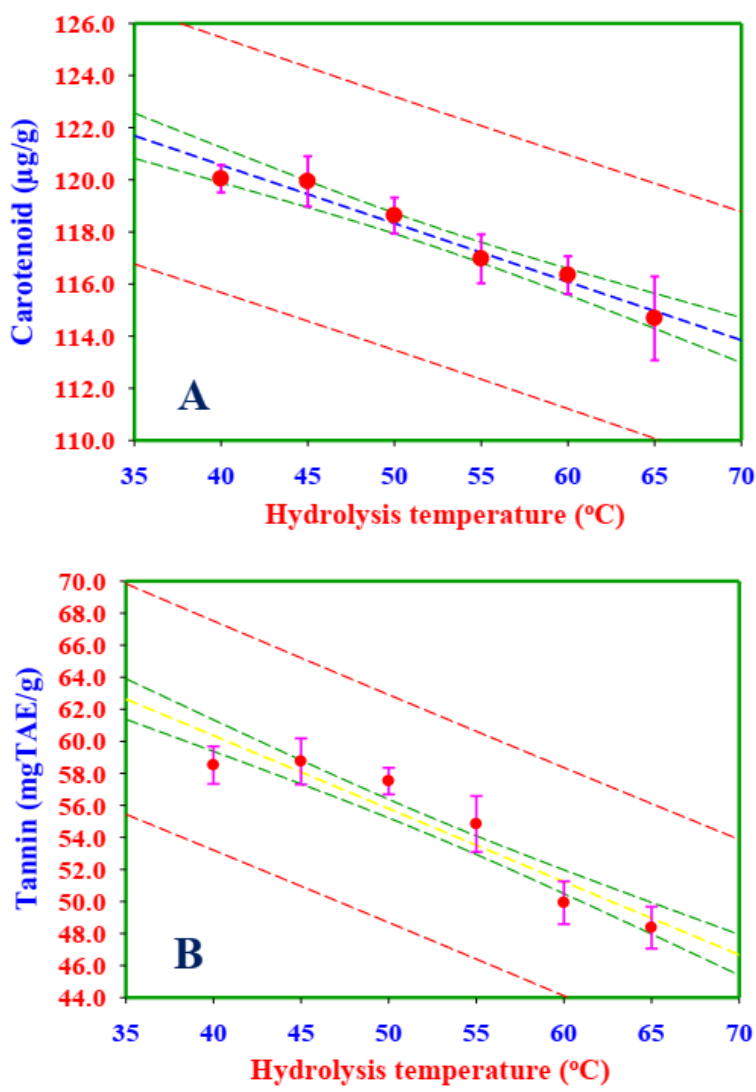

Figure 5. Effect of hydrolysis temperature on (A) carotenoid and (B) tannin

Figure 5 illustrates how temperature affected hydrolysis efficiency $(\mathrm{p}<0.05)$. Overall, it is clear that both carotenoid and tannin declined when temperature increased. There was a significant decrease in carotenoid and tannin, from $120.04 \pm 13.13(\mu \mathrm{g} / \mathrm{g})$ and $58.51 \pm 3.57(\mathrm{mgTAE} / \mathrm{g})$, respectively at $400^{\circ} \mathrm{C}$ to $116.34 \pm 17.97(\mu \mathrm{g} / \mathrm{g})$ and $49.92 \pm 3.32(\mathrm{mgTAE} / \mathrm{g})$, respectively at $600^{\circ} \mathrm{C}$, which continued to experience a fall to respective $114.68 \pm 3.98(\mu \mathrm{g} / \mathrm{g})$ and $48.37 \pm 3.24(\mathrm{mgTAE} / \mathrm{g})$ at 650C. This can be explained by the breakdown of plant tissue and the release of biological compounds in the material owing to increased temperature. In addition, most biological compounds are sensitive to high temperatures that will lead to the decomposition of these compounds.

As for the correlation between antioxidant activity (expressed through IC50 value) and TPC as far as temperature is concerned, Figure 6 shows that the $\mathrm{R} 2$ value of the regression equation was quite high (0.981), allowing confirmation of polyphenol 
compounds that contribute to the antioxidant activity of Pouteria campechiana extract. From the results obtained above, a hydrolysis temperature of $600 \mathrm{C}$ was selected for further experiments.

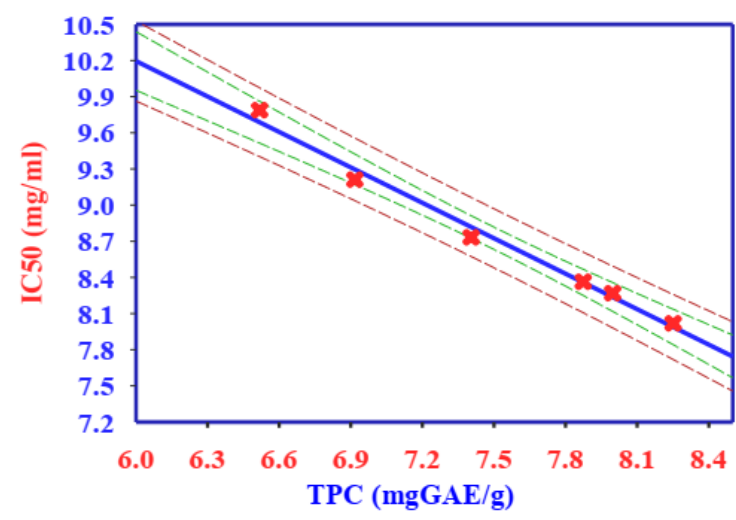

Figure 6. Correlation between IC50 and TPC by hydrolysis temperature

\section{Effect of hydrolysis time}

Choosing appropriate hydrolysis time is the last step in the experimental series, and the hydrolysis time is also an important factor that affects hydrolysis. Hydrolysis was conducted during 4570 minutes under fixed conditions, including $\mathrm{pH} 5$, pectinase enzyme concentration of $0.6 \mathrm{wt} \%$, cellulase enzyme concentration of $0.6 \mathrm{wt} \%$, and hydrolysis temperature of $600^{\circ} \mathrm{C}$.

It is obvious from Figure 7, which shows how hydrolysis time has effects on carotenoid and tannin that carotenoid and tannin decreased substantially with time and reached a peak of $115.14 \pm 4.14(\mu \mathrm{g} / \mathrm{g})$ và $45.88 \pm 2.37(\mathrm{mgTAE} / \mathrm{g})$, respectively by 65 minutes. The prolonged hydrolysis time of the enzyme is necessary to produce a large volume of extract. However, too long- hydrolysis time does not produce more extract but may take longer, sometimes reduces some components in the extract. Accordingly, the longer the hydrolysis occurs, the lower the amounts of carotenoid and tannin of the extract $(113.59 \pm 2.55 \mu \mathrm{g} / \mathrm{g}$ and $38.03 \pm 2.55 \mu \mathrm{mgTAE} / \mathrm{g}$, respectively by 70 minutes). Thus, the optimal time for hydrolysis was 65 minutes
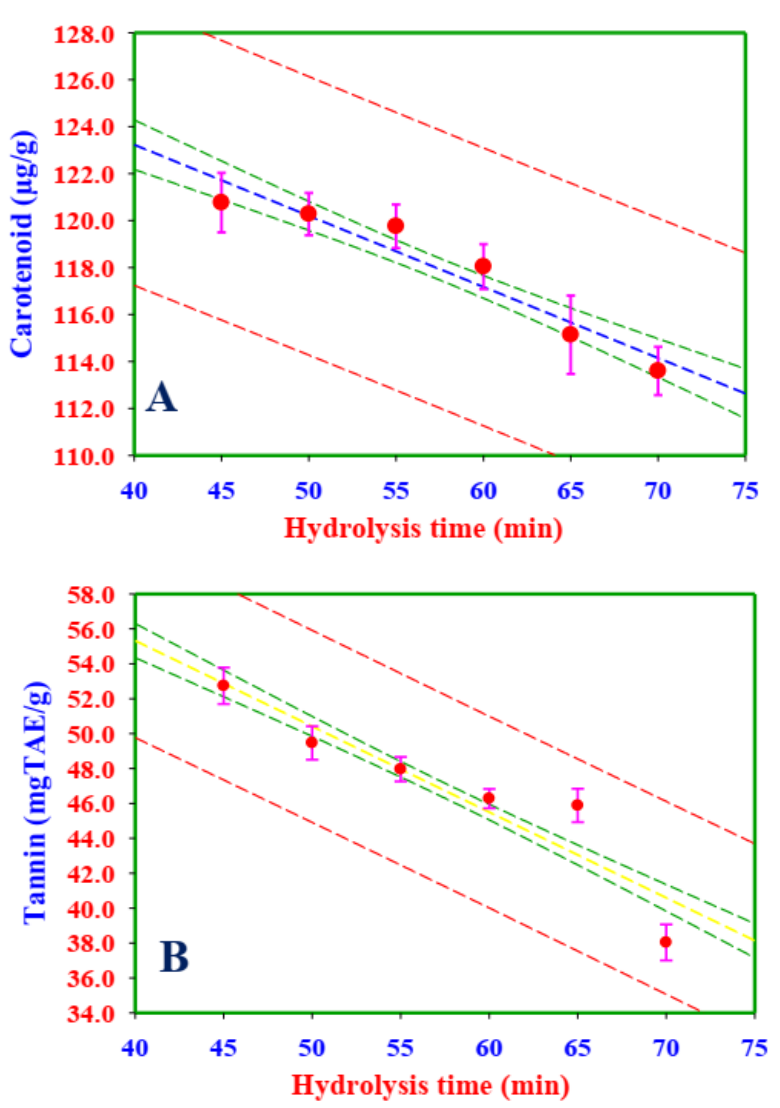

Figure 7. Effect of hydrolysis time on (A) carotenoid và $(B)$ tannin

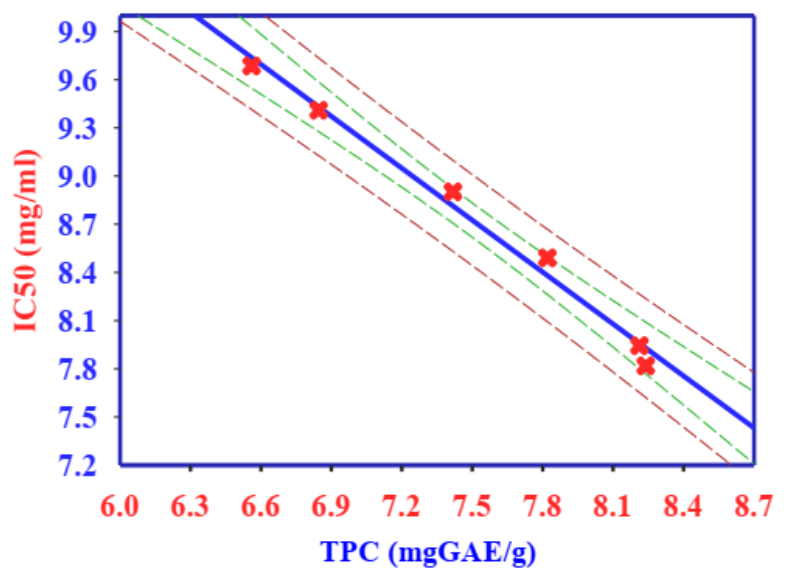

Figure 8. Correlation between IC50 and TPC by hydrolysis time

Regarding the correlation between IC50 and TPC values in Figure 8 as far as hydrolysis time is concerned, the regression equation had R2 $=0.980$ when IC50 decreased from $8.19 \pm 0.11(\mathrm{mg} / \mathrm{mL})$ to $7.82 \pm 0.21 \quad(\mathrm{mg} / \mathrm{mL})$, which can confirm that 
polyphenol compounds played a major role in the Pouteria campechiana extract.

\section{CONCLUSIONS}

Based on this study, it can be seen that hydrolysis of Pouteria campechiana fruit under the effect of enzymes altered the carotenoid, tannin, and antioxidant activity through IC50 value in the Pouteria campechiana extract. The optimal conditions for hydrolysis were to hydrolyze at $600^{\circ} \mathrm{C}$ for 65 minutes with a concentration of 0.6 $\mathrm{wt} \%$ for both pectinase and cellulase enzymes. Carotenoid and tannin of the extract reached the highest value of respective $115.14 \pm 4.14(\mu \mathrm{g} / \mathrm{g})$ and $45.88 \pm 2.37(\mathrm{mgTAE} / \mathrm{g})$, and antioxidant activity through the correlation between IC50 and TPC values were very high $(\mathrm{R} 2=0.98)$ with $\mathrm{IC} 50=$ $7.82 \pm 0.21(\mathrm{mg} / \mathrm{mL})$. The results of the study contributed to the provision of valuable scientific data on Pouteria campechiana fruit, which is essential for its effective use.

\section{REFERENCES}

Apostolidis, E., Lajolo, F. M., Genovese, M. I., Pinto, M. S., Ranilla, L. G., \& Shetty , K. (2009). Evaluation of antihyperglycemic and antihypertension potential of native Peruvian fruits using in vitro models. Journal of Medicinal Food, 12, 278-91.

Czukor, B., \& Nyarady, Z. F. (1999). Production of high-fiber products by enzymatic treatment. In Euro food chem. Budapest, Hungary, FECS Event., 234, 335-342.

Demir, N., Acar, J., Sarioglu, K., \& Mutlu, M. (2001). The use of commercial pectinase in the fruit juice industry. Part 3: Immobilized pectinase for mash treatment. Journal of Food Engineering, 47 (4), 275 280.
Duarte, Odilo, Paull, \& Robert. (2015). Exotic Fruits and Nuts of the New World. CABI, $117-123$

Jiang, S., Cai, W., \& Xu, B. (2013). Food Quality Improvement of Soy Milk Made from Short-Time Germinated Soybeans Food. 2, 198-212.

Laitonjam, W. S., Yumnam, R., Asem, S. D., \& Wangkheirakpam, S. D. (2013). Evaluative and comparative study of biochemical, trace elements and antioxidant activity of Phlogacanthus pubinervius T. Anderson and Phlocanthus jenkinci C.B. Clarke leaves. Indian Journal of Natural Products and Resources, 4(1), 67-72.

Miliauskas, G., Venskutonis, P. R., \& Beek, T. A. (2004). Screening of radical scavenging activity of some medicinal and aromatic plant extracts. Food Chemistry, 85, 231237.

Singh, A., Kuila, A., Yadav, G., \& Banerjee, R. (2011). ProcessOptimization for the Extraction of Polyphenols from Okara. Food Technology Biotechnol, 49 (3), 322328.

Sreenath, H. K., \& Santhanam, K. (1992). The use of commercial enzymes in white grape juice.

Will, F., Bauckhage, K., \& Dietrich, H. (2000). Apple pomace liquefaction with pectinase and cellulase: analytical data of the corresponding juices. European Food Research and Technology, 211 (4), 291297.

Yahia, E. M., \& Orozco, G. (2011). Lucuma (Pouteria lucuma). Mexico: Autonomous University of Queretaro. 